Research Article

\title{
Government Intervention in Pakistan's Rice Sector: Concepts, Policies and Implications
}

\author{
Reema Zia* and Noor Paio Khan
}

Institute of Development Studies (IDS), Faculty of Rural Social Sciences, The University of Agriculture, Peshawar, Pakistan.

\begin{abstract}
This study was designed to introduce Producer Subsidy Equivalent (PSE) and Subsidy Ratio to Producer (SRP), the celebrated tools of political economy, to gauge government intervention in Pakistan's rice sector and draw policy implications for possible adjustments in policies and future strategy. The quantitative analyses of PSE and SRP reveals overall transfers from rice producers to society. The analysis depicts Pakistan's stronger position towards WTO trade liberalization in the rice sector. Pakistan would not need to change any of its policies and would benefit from trade liberalization due to the expansion of rice production when world prices of rice rise as a result of the reduction of support in other countries.

Received | March 03, 2021; Accepted | July 01, 2021; Published | September 03, 2021

*Correspondence | Reema Zia, Institute of Development Studies (IDS), Faculty of Rural Social Sciences, The University of Agriculture, Peshawar- Pakistan; Email: reemazia800@gmail.com

Citation | Zia R. and N.P. Khan. 2021. Government intervention in Pakistan's rice sector: concepts, policies and implications. Sarhad Journal of Agriculture, 37(4): 1244-1249.

DOI | https://dx.doi.org/10.17582/journal.sja/2021/37.4.1244.1249

Keywords | Producer Subsidy Equivalent (PSE), Subsidy Ratio to Producer (SRP), Policy Analysis Matrix (PAM), Rice
\end{abstract}

\section{Introduction}

Dakistan's government intervention in agriculture Pis a complex web of contradictory policies particularly its support to agricultural production, taxation of agricultural exports and its consumer subsidy on food and fiber (Chaudhry, 2001). Given the cultural, socio-political, and economic importance of rice in Pakistan's economy, the government cannot afford to leave its rice sector freely influenced by global market forces of demand and supply. Invariably, the governments have intervened in its rice sector with an attempt to reconcile the conflicting objectives of diverse interest groups i-e consumers, producers, importers and society (SBP, 2012). Inter alia, sectorspecific policies (investment in agricultural education and research, technology and extension and economy wide policies i.e. exchange rates, industrial protection, interest rates, and market infrastructure) also have altered the incentive structure for the rice farmers.

It is generally believed that these policies have inflicted substantial social costs on the economy by misallocating resources, accumulating huge budget and trade deficits. The government has already started work on reducing distortions in the economy through structural adjustment for alleviating huge budget deficits and improving management and production efficiency (Khan, 2002).

The recent trends of trade liberalization have seriously affected Pakistan's terms of trade and it seems that such global market forces are becoming major determinants of the pattern of agricultural production and trade in the future. The Agreement on Agriculture (AoA) requires both developed and developing countries major reductions in tariff, domestic support and export subsidies over an agreed 
period of time. Being a signatory of the WTO, the government of Pakistan will have to phase out its reduction of protection and support to agriculture and must be prepared to compete in the changing world of trading markets (Malik, 2015).

This study is spadework to introduce innovative concepts and techniques to gauge government intervention in agriculture, predict possible adjustments in Pakistan's rice sector and draw policy implications for the future strategy of production and trade.

\section{Materials and Methods}

The Producer Subsidy Equivalents (PSEs) and Subsidy Ratio to Producers (SRP) analyses are used to gauge government intervention in Pakistan's rice sector (Basmati and IRRI) in farming region of Punjab and Sindh for the harvesting years 2013-14 and 2017-2018. The estimates of costs and returns of rice production are based on the data from the Agriculture Policy Institute (API) that was further supplemented by wholesale prices, FOB and CIF of inputs and outputs to get representative budgets for the selected crops and data from other sources such as annual reports, Agricultural Statistics and Economic Survey of Pakistan (various issues).

Rice (Oryza Sativa L.) is a monsoon, water and laborintensive crop and is grown throughout the country with Punjab being the leading province in terms of Basmati variety. Rice was cultivated on 11 percent of the country's land and is the third-largest crop and also source of foreign exchange earnings. Its contribution to GDP was 0.7 percent while 3.1 percent to the value-added sector. China, India, USA, Vietnam, Thailand and Burma are the main competitors of rice in the international market (GoP, 2018).

\section{Analytical framework}

Applied and political economists use a variety of indicators to gauge policy effects of government intervention in agriculture. They use border prices as shadow prices because these prices would prevail in the free market settings. The divergence between market and border price can be used to indicate policy effects. The Producer Subsidy Equivalents (PSEs) and Subsidy Ratio to Producers (SRP) use the divergences between market price and border price as policy effects of government intervention in agriculture.

Producer Subsidy Equivalents (PSEs)

Pressed by stronger demands to bring agriculture into General Agreement on Tariff \& Trade (GATT) negotiations, agricultural trade specialists were seeking an alternative measure with broader information content on domestic and border distortions. Josling (1973) proposed the notion of Producer Subsidy Equivalent (PSE), the level of producer subsidy that would be necessary for the removal of array of government farm policies employed in a particular country in order to leave farm income unchanged. The PSE formulation includes distortions in traded inputs $\mathrm{qt}\left(\mathrm{pt}^{*}-\lambda^{1} \mathrm{pt}\right)$ as well as in domestic factormarkets qn $\left(\mathrm{pn}^{*}-\mathrm{pn}\right)$ and outputs qo$\left(\mathrm{po}^{*}-\lambda \mathrm{po}\right)$. The "total" PSE is defined as;

$$
\operatorname{PSE}_{\text {Total }}=q_{o}\left(p_{o}^{*}-\lambda p_{o}\right)-q_{t}\left(p_{t}^{*}-\lambda p_{t}\right)-q_{n}\left(p_{n}^{*}-p_{n}\right)(1)
$$

PSE "total" is denominated in specific units such as dollars per tons and is useful to quantify the policy effects of particular scale of activity. However, agricultural activities are expressed usually in different units of measurement, which makes PSE "total" difficult to compare across different activities and countries. Masters and Nelson (1995) has resolved the issue by converting PSE "total" into a unit-free percentage by using PSE "total" as a proportion of market revenue (po* qo);

$$
\mathrm{PSE}=\frac{\mathrm{PSE}_{\text {Total }}}{\left(p_{o}^{*} q_{o}\right)}
$$

Since 1980s, the percentage PSE quickly became a standard measure in GATT negotiations and policy debates to reduce state intervention in agriculture, liberalize commodity trade and harmonize agricultural policies of member countries. PSEs are also used as a test of compliance in other trade treaties (e.g., NAFTA and EC).

\section{The Subsidy Ratio to Producers (SRP)}

Percentage PSE is expressed as a proportion of distorted producer revenue (po* qo), valued at market prices and not valued at social prices ( $\lambda$ po qo). It may give different levels of total PSE, depending on the "mix" of policies between input subsidies and output price supports. More specifically, a percentage PSE understates agricultural protection in countries supporting output prices relative to countries 
subsidizing factor markets.

Monke and Pearson (1989) resolved the discrepancy between total and percentage PSE by writing total PSE as a proportion of social revenue in lieu of market revenue. This is a net policy transfer to producers as a proportion of total social revenue and may be defined as Subsidy Ratio to Producers (SRP);

$$
\mathrm{SRP}=\frac{\mathrm{PSE}_{\text {Total }}}{\left(\lambda p_{o} q_{o}\right)}(3)
$$

SRP uses the same information as percentage PSE, but has an advantage of being a tariff-equivalent measure like NPC and EPC. Thus, the SRP aggregates most of the criteria of a good indicator of policy effects and therefore deserves to be a celebrated instrument of political economy.

\section{Results and Discussion}

The political economy of Pakistan has a complex history of government intervention in agriculture. The main policies covered by this study are sectorspecific (investment in agricultural education and research, technology, extension, irrigation, price support and input subsidies) and economy-wide policies (exchange rates, industrial protection, interest rates, and market infrastructure). The government plan for un-interrupted payment of the foreign debt has been ensured by regulating the export of rice through trading and marketing boards over the years. The economic importance of rice led to subsidize rice as cheap input to promote a value addition industry. Rice being the staple, the poor were guaranteed a low and stable price directly through the ration system and occasional open-market releases while indirectly, through restricted trade, which insulated consumers from world price fluctuations. The government has also maintained a reasonable and remunerative return to rice farmers through price support systems (FAO, 2018).

The results of Producer Subsidy Equivalents (PSEs) and Subsidy Ratio to Producers (SRP) analyses are presented to gauge the level of government intervention in Pakistan's rice sector for the harvesting years 2013-14 and 2017-18. The positive values of PSEs and SRP for the harvesting year 2013-14 in Table 1 indicate overall transfers from consumers and taxpayers to Basmati producers in Punjab (Pakistan) when the rice is produced for export promotion. The analyses further reveal that the production and export of Basmati are positively supported to the extent of 14 percent (PSE) and 16 percent (SRP) in Punjab (Pakistan). The negative values of PSEs and SRP in the harvesting year 2017-18 indicates overall transfers from Basmati producers to society, when it is produced for export purpose. The production and export of Basmati are implicitly taxed during this year. The analyses further show that the incidence of taxation is 68 percent (PSE) and 40 percent (SRP) in Punjab (Pakistan).

Table 1: PSE and SRP of Basmati Paddy (2013-14 E 2017-18).

\begin{tabular}{|c|c|c|c|c|}
\hline \multirow{3}{*}{$\begin{array}{l}\text { Country/ } \\
\text { Province }\end{array}$} & \multicolumn{4}{|c|}{ Export Promotion Regime } \\
\hline & PSE & & SRP & \\
\hline & 2013-14 & $2017-18$ & 2013-14 & $2017-18$ \\
\hline Pakistan & 0.14 & -0.68 & 0.16 & -0.40 \\
\hline Punjab & 0.14 & -0.68 & 0.16 & -0.40 \\
\hline Sindh & -- & -- & -- & -- \\
\hline
\end{tabular}

Source: Author's Calculation from Policy Analysis Matrix (PAM) Budgets

Note: Basmati is not cultivated in Sindh

Table 2: PSE and SRP of IRRI Paddy (2013-14 Eं 2017-18).

\begin{tabular}{lllll} 
Country/ & \multicolumn{4}{l}{ Export Promotion Regime } \\
Province & PSE & & SRP \\
& $2013-14$ & $2017-18$ & $2013-14$ & $2017-18$ \\
& 0.35 & 0.35 & 0.46 & 0.45 \\
Pakistan & 0.31 & 0.23 & 0.42 & 0.28 \\
Punjab & 0.23 & 0.28 & 0.30 & 0.36
\end{tabular}

Source: Author's Calculation from Policy Analysis Matrix (PAM) Budgets

The PSE and SRP analyses for IRRI rice paddy is summarized in Table 2 for the harvesting years 201314 and 2017-18. The positive values for PSE and SRP imply overall transfers from society to IRRI producers for both the harvesting years in all farming regions. The analyses further reveals that in year 201314 , IRRI producers were positively supported to the extent of 35 percent (PSE) and 46 percent (SRP) in Pakistan, 31 percent (PSE) and 42 percent (SRP) in Punjab, and 23 percent (PSE) and 30 percent (SRP) in Sindh. The IRRI production and export for the harvesting year 2017-18 was supported to the extent of 35 percent (PSE) and 45 percent (SRP) in Pakistan, 23 percent (PSE) and 28 percent (SRP) in Punjab, 
and 28 percent (PSE) and 36 percent (SRP) in Sindh.

Rice is used both as cash and staple crop. One of the major reasons for negative PSEs and SRPs for Basmati is that the price of rice as a staple was kept low to benefit the consumers along with other policy factors such as state control of production, marketing and trade and distorted macroeconomic policies (e.g.; exchange rate). The positive PSE and SRPs for Basmati implies that production of Basmati for the export purpose will need government positive support to the extent of 14 percent (PSE) and 16 percent (SRP) in Punjab (Pakistan). Similarly, the PSEs and SRPs analyses for IRRI suggest the activity will demand government financial support to continue the production and export of that commodity which is not possible given the current campaign of WTO to reduce government support to agriculture.

\section{Pakistan's position toward WTO agricultural trade liberalization}

The literature on international economics and trade is full of evidences on the positive contribution of free and fair trade to increased total production and net gains to society. Free trade is determined by the principle of comparative advantage, stating that two nations can benefit from mutual trade if each nation specializes in the production of a commodity for which it has lower opportunity cost. The recent trend of agricultural trade liberalization under WTO is a step towards free trade. However, the effects of trade liberalization would vary from country to country depending on their natural endowments, competitiveness, tariff and protection structure, institutional arrangements and mix of sectoral and economy-wide policies (Monke and Pearson, 1989; Nelson and Panggabean, 1994; Masters and Winter-Nelson, 1995; Khan, 1997; Ali and Khan, 2012).

The PSE and SRP analyses depict Pakistan's stronger position towardsWTO agricultural tradeliberalization in general and to the rice sector in particular. Pakistan would not need to change any of its agricultural policies because its aggregate PSE is either negative or positive but lower than the agreed level of Aggregate Support to Agriculture under WTO. If world prices rise for rice as a result of the reduction of support in other countries, Pakistan would reap the benefits of trade liberalization due to the expansion of rice production and trade. Pakistan would benefit more than any other developing country under uniform and full implementation of WTO trade reforms (FAO, 2000). Several other studies, (Chaudhry, 2020; Sharif et al., 2016; Ali and Khan, 2012; Rehman et al., 2011) have anticipated considerable expansion in Pakistan's agricultural production and trade as a result of tariff reductions, relaxation of quota restrictions, removal of export subsidies and reduced Aggregate Measure of Support (AMS) in most of the developed countries.

\section{Conclusions and Recommendations}

The 1980s and first half of the 1990s was an active period in the field of the political economy of agricultural protection, where several important recent international developments brought the political economy of agriculture and food policy back to the top of the international trade and development agenda. The failure to reach an agreement on free and fair trade under WTO umbrella, the global food crisis and spike in food inflation has drawn our attention to the role of political considerations and the failure of agricultural and macroeconomic policies to stimulate investment in agricultural research, technology, extension and production. To fill this gap, there is an urgent need to command new studies on the political economy of agricultural distortions, estimation of aggregate support to agriculture, and welfare gains from trade liberalization.

The study has already forwarded suggestions in the text, however, the most important recommendations are summarized as follow:

1. Punjab shows comparative advantage in Basmati paddy production for export purpose, therefore honest and sincere efforts are required from those who are responsible for Research and Development (R\&D), bureaucrats, and policymakers to formulate agricultural and macroeconomic policies which may strengthen the existing comparative advantage of Basmati paddy.

2. Punjab has a comparative disadvantage in IRRI paddy production for export purposes, the government should therefore discourage IRRI production in Punjab so that the scarce resources are liberated and utilized for the cultivation of Basmati and cotton in the province.

3. The study further shows that Sindh has the comparative advantage in IRRI production which should be further strengthened by improving 
yield, quality, and marketing infrastructure of IRRI paddy for export purpose, in addition to supporting the IRRI production through subsidies and supports.

4. The findings of the study reveal that Basmati and IRRI yield in Pakistan is far below that of the other rice-growing countries of the world. Therefore, it should be the top priority of the government and other stakeholders to initiate research for the introduction of a high-yielding variety of paddy rice that is disease tolerant and less water consuming.

5. The study further suggests that world reference price must be ensured to Basmati growers in Pakistan to further encourage Basmati production and export.

6. Finally, the agriculture sector and macroeconomic policies particularly related to agriculture output and inputs must be announced and outreached well in time to the farmers and other stakeholders. It is further recommended that at the provincial, district and tehsil level, a market information system (MIS) must be established to update the farmers and relevant authorities about the prices of output and inputs.

\section{Novelty Statement}

This research highlights the role of government intervention in the major export crop of Pakistan i.e. Rice by using the tools of the Producer Subsidy Equivalent (PSE) and Subsidy Ratio to the Producer (SRP).

\section{Author's Contribution}

Reema Zia: Principal author, who did research, analyze the data and wrote draft of the manuscript.

Noor Paio Khan: Major Supervisor, who designed research and provided technical guidelines in the whole study.

\section{Conflict of interest}

The authors have declared no conflict of interest.

\section{References}

Ali, G. and N.P. Khan. 2012. Government intervention in Pakistan's sugarcane sector, Policy Analysis Matrix (PAM) Approach.
Sarhad J. Agric. 28(1): 104-107. Web adress: https://agris.fao.org > agris-search > search > recordID

API. 2014. Rice paddy policy analysis for 2014-15 crop. Agriculture policy institute. Ministry of food, agriculture and livestock, GoP, Islamabad.

API. 2018. Rice paddy policy analysis for 2017-18 crop. Agriculture policy institute. Ministry of food, agriculture and livestock, GoP, Islamabad.

Chaudhry, M.G. 2001. Impact of WTO negotiations on agriculture in Pakistan and implications for policy. Pak. J. Agric. Econ. 4: $1-14$.

Chaudhry, S.M.Z. 2020. Construction of a Policy Analysis Matrix (PAM) for Fruits and Vegetables Export Process in Bangladesh. Turk Res. J. Acad. Soc. Sci., 3(1): 11-21. Web Address: http://www.turkishsocialscience.com/ FAO. 2000. The impact of trade liberalization on production of agricultural commodities and related fertilizer use to 2000”. FAO. Rome, Italy. Web Address: http://www.fao.org/3/y4671e/ y4671e.pdf

FAO. 2018. Food and agriculture organization of United Nations. 2018. Rice Market Monitor,Trade and Market Division. 21(1): 1-35. Web Address: http://www.fao.org/economic/ est/publications/rice-publications/rice-market-monitor-rmm/en/

GoP. 2018. Agricultural Statistics of Pakistan 2018. Government of Pakistan, Ministry of Food, Agriculture and Livestock, Islamabad. Web Address: http://www.mnfsr.gov.pk/

Josling, T.E. 1973. Agricultural Protection: Domestic policy and international trade. FAO, Rome, 1973.

Khan, N.P. 1997. Comparative advantage of US agriculture and effect of policy on agricultural development and trade. The Policy Analysis Matrix Approach, unpublished PhD thesis, Department of Agricultural Economics, University of Kentucky, USA. Pp: 1-49.

Khan, N.P. 2002. Government Intervention in Pakistan's wheat and cotton sectors concepts, policies and implications. Department of Agricultural Economics, NWFP Agricultural University, Peshawar, Pakistan. Asian J. Plant Serv. 44(1): 492-494. https://doi.org/10.3923/ ajps.2002.492.494

Malik. S.J. 2015. Agriculture policy in Pakistanwhat it should be? Pakistan Institute of De- 
velopment Economics. April 24, 2015.https:// www.pide.org.pk/pdf/Seminar/AgriculturePolicyPakistan.pdf

Master and A.W. Nelson. 1995. Measuring the comparative advantage of agriculture activities: Domestic resource cost and social cost benefit ratio. Am. J. Agric. Econ. 77(2): 243-250. https://doi.org/10.2307/1243534

Monke, E. and S.R. Pearson. 1989. The policy analysis matrix for agricultural development. Cornell University Press, Ithaca, NY., USA., ISBN-13: 9780801419539, Pages: 279.

Nelson, G.C. and M. Panggabean. 1991. The cost of Indonesian Sugar Policy: The Policy Analysis Matrix Approach. Am. J. Agric. Econ. 73. https://doi.org/10.2307/1242822

Rehman, A, N.P. Khan., I. Khan., M. Nazir., M.
Khan., D. Jan and A. Ali. 2011. Comparative advantage and policy analysis of Wheat in district D.I. Khan of Khyber Pakhtunkhwa. Department of Agricultural Economics, Khyber Pakhtunkhwa Agricultural University Peshawar Pakistan. Interdisciplinary J. Contemp. Res. in Busi., 3(8): 982-1008. Web Address: https:// www.researchgate.net/publication/

SBP. 2012. Basmati Rice Value Cain in Pakistan. State Bank of Pakistan, Department of Agricultural Credit and Micro Finance. Pp.1626. Web Address: https://www.sbp.org.pk/ publications/ChainReport/2012

Sharif, M., M.A. Niazi., A.B. Mahar and A. Jabbar. 2016. Study on competitiveness of cereals and their products exports from Pakistan. J. Agric. Res., 53(3): 453-465. 